\title{
PERLINDUNGAN HUKUM BAGI BANK (KREDITUR) BILA DEBITUR KREDIT MACET DENGAN JAMINAN HAK CIPTA
}

\author{
Oleh : \\ Riandhyka Rahandono, Azizul Hakiki, Achmad Rifqi Nizam \\ Email : ryandhykar@gmail.com
}

\begin{abstract}
One of the economic development forms is the existence of the developed companies in all fields, both services and goods. In order to be able to develop a company in line with the plan and to be successful, it certainly needs capital support (fund) which can be obtained from Banking Institution with a collateral form called Patent Right. This research is juridical-normative (legal research), that is the research focused on analysing rules or norms in positive law. The research concludes that Patent Right can be made as the main collateral of credit agreement because it can be categorized as intangible moving object which has economic value. However, because Patent Right is a new collateral form, it is difficult to assess its economic value and there is no regulation of it. In practice the Banking Institution has not been able to accept Patent Right as the main collateral, but only as additional collateral.
\end{abstract}

Key Words : Bank, Collateral, Patent Right. 


\section{PENDAHULUAN}

\subsection{Latar Belakang}

Salah satu wujud pembangunan ekonomi yaitu ditandai dengan berkembangnya perusahaan-perusahaan di segala bidang usaha, baik dibidang jasa maupun barang. Agar dapat mengembangkan perusahaan sesuai dengan rencana dan sukses tentunya diperlukan dukungan dari berbagai komponen, salah satu komponen tersebut adalah bidang modal (dana) untuk dapat mengembangkan usaha guna memenuhi atau memperbesar produksi barang/jasa yang dibutuhkan oleh masyarakat, dalam memperoleh dana ini dapat diperoleh dengan melalui berbagai macam sumber, baik dari pribadi maupun yang berbentuk Lembaga Perbankan.

Bank merupakan salah satu bentuk lembaga keuangan. Undang-Undang Nomor 10 Tahun 1998 tentang Perubahan UU nomor 7 Tahun 1992 tentang Perbankan (selanjutnya disebut UU Perbankan) pada pasal 1 angka (2) menyebutkan :

"Bank adalah badan usaha yang menghimpun dana dari masyarakat dalam bentuk simpanan dan menyalurkannya kepada masyarakat dalam bentuk kredit dan atau bentukbentuk lainnya dalam rangka meningkatkan taraf hidup rakyat banyak."

Sebagai bentuk perwujudan dari prinsip kehati-hatian (prudential banking principle), adalah UU Perbankan pasal 8, yaitu:

"Bank wajib mempunyai keyakinan dengan berdasarkan analisis yang mendalam atas itikad baik dan kemampuan serta kesanggupan nasabah atau debitur untuk melunasi utangnya atau mengembalikan pembayaran dimaksud sesuai dengan yang diperjanjikan".

Undang-Undang Perbankan secara tersurat tidak secara tegas menyebutkan adanya suatu jaminan dalam perjanjian kredit, hanya saja mengingat dana yang disalurkan merupakan dana milik masyarakat, maka Bank harus dapat menjamin bahwa dana tersebut harus kembali lagi kepada masyarakat, yaitu dengan adanya suatu jaminan terhadap kredit yang dikucurkan kepada Debitur.

Pada dasarnya jaminan dalam dunia perbankan dapat dibedakan ke dalam jaminan umum dan jaminan khusus. Jaminan umum adalah jaminan yang diberikan bagi kepentingan semua kreditur dan menyangkut semua harta kekayaan debitur. Benda jaminan itu tidak ditunjuk secara khusus dan tidak diperuntukkan untuk seorang kreditur. Jaminan umum 
timbul dari Undang-undang, yaitu berdasarkan Pasal 1131 KUHPerdata yang menyebutkan bahwa segala kebendaan si berhutang, baik yang bergerak maupun yang tidak bergerak, baik yang sudah ada maupun yang baru akan ada di kemudian hari, menjadi tanggungan untuk segala perikatan seseorang. Jaminan khusus adalah jaminan yang diperjanjikan terlebih dahulu antara pihak yang berkepentingan. ${ }^{1}$

Jaminan khusus dapat dibedakan menjadi beberapa bentuk, antara lain sebagai berikut:

1. Gadai, diatur dalam Pasal 1150-1160 KUHPerdata, mengatur tentang jaminan khusus atas benda bergerak;

2. Hipotik, diatur dalam Pasal 1162-1232 KUHPerdata, mengatur tentang jaminan atas benda tidak bergerak;

3. Hak Tanggungan, diatur dalam Undangundang Nomor 4 Tahun 1996 tentang Hak Tanggungan;

4. Jaminan Fidusia, diatur dalam Undangundang Nomor 42 Tahun 1999 tentang Jaminan Fidusia. ${ }^{2}$

Jaminan Fidusia merupakan suatu bentuk pembebanan benda bergerak baik berwujud maupun tidak berwujud. Salah satu benda bergerak tidak berwujud yang dapat dijadikan jaminan adalah Hak Kekayaan Intelektual (HKI). Istilah Hak

1 Sutarno. Aspek-aspek Hukum Perkreditan Pada Bank. (Bandung: Alfabeta, 2009), hlm 146

${ }^{2}$ Sentosa Sembiring.Hukum Perbankan. (Bandung: Mandar Maju, 2000), hlm 73 milik Intelektual atau Hak Kekayaan Intelektual merupakan terjemahan langung dari intelectual property. Selain istilah intellectual property,juga dikenal dengan istilah intangible property,creative property dan incorporeal property. Di Perancis orang menyatakannya sebagai propriete intelectuelle dan propriete industrielle.di Belanda biasa disebut milik intelektual dan milik perindustrian. ${ }^{3}$

Hak Kekayaan Intelektual (HKI) atau intellectual property rights adalah hak umum yang bersifat ekslusif (khusus) yang dimiliki oleh para pencipta/penemu sebagai hasil aktivitas dan kreativitas yang bersifat khas atau baru. Karya-karya intelektual tersebut dapat berupa hasil karya cipta di bidang ilmu pengetahuan, seni dan sastra serta hasil penemuan (invensi) di bidang teknologi. Karya-karya di bidang HKI dihasilkan berkat kemampuan intelektual manusia melaui pengorbanan tenaga, waktu, pikiran, perasaan, dan hasil intuisi/ilham/hati nurani. ${ }^{4}$

Hak Cipta merupakan bagian dari Hak Kekayaan Intelektual (HKI) atau intellectual property rights, menurut Pasal

\footnotetext{
3 Muhammad Djumhana dan R. Djubaedillah.Hak Milik Intelektual (Sejarah, Teori dan Prakteknya Di Indonesia).(Bandung: Citra Aditya Bakti,2003), hlm 21

4 Iswi Hariyani.Prosedur Mengurus HAKI (Hak Atas Kekayaan Intelektual) yang benar (Yogyakarta: Penerbit Pustaka Yustisia, 2010), hlm 46
} 
1 angka 1 Undang- Undang Nomor 28

Tahun 2014 tentang Hak Cipta(untuk selanjutnya disebut UU Hak Cipta),

"Hak Cipta adalah hak eksklusif pencipta yang timbul secara otomatis berdasarkan prinsip deklaratif setelah suatu ciptaan diwujudkan dalam bentuk nyata tanpa mengurangi pembatasan sesuai dengan ketentuan peraturan perundang-undangan".

Hak Cipta merupakan intangible property atau intangible asset, dalam Hukum Benda termasuk benda bergerak tidak berwujud, karena merupakan benda, maka Hak Cipta dapat dijadikan jaminan dalam perjanjian kredit. UU Hak Cipta pasal 16 ayat 3: "Hak Cipta dapat dijadikan sebagai objek jaminan fidusia".

\subsection{Rumusan Masalah}

Berdasarkan latar belakang yang telah dipaparkan di atas, maka permasalahan yang akan diteliti dapat dirumuskan sebagai berikut;

1. Apakah Hak Cipta dapat dijadikan sebagai Jaminan Pokok dalam Perjanjian Kredit ?

2. Apakah akibat hukum bagi Bank (Kreditur) bila Debitur wanprestasi dalam perjanjian Kredit dengan Jaminan Hak Cipta?

3. Apa upaya penyelesaian yang dapat dilakukan Bank (Kreditur) dalam menyelesaikan Kredit Macet dengan Jaminan Hak Cipta?

\section{METODE PENELITIAN}

Penelitian adalah suatu proses untuk menemukan aturan hukum, prinsip-prinsip hukum maupun doktrin-doktrin hukum guna menjawab isu hukum yang dihadapi. ${ }^{5}$ Tipe penelitian yang digunakan adalah yuridis normatif, yakni penelitian yang difokuskan untuk mengkaji penerapanpenerapan kaidah atau norma-norma dalam hukum positif yang berlaku. Metode pendekatan yuridis normatif dilakukan dengan cara mengkaji berbagai aturan hukum yang bersifat formil seperti undang-undang, peraturan-peraturan serta literatur yang berisi konsep teoritis yang kemudian dihubungkan dengan permasalahan yang akan dibahas dalam skripsi ini. ${ }^{6}$

Pendekatan masalah yang digunakan dalam penulisan skripsi ini adalah Pendekatan Undang-Undang (statute approach) dan pendekatan Konseptual (conceptual approach). Pendekatan Undang-Undang (statute approach) dilakukan dengan menelaah semua undang undang dan regulasi yang bersangkut paut dengan isu hukum yang sedang ditangani. Suatu penelitian normatif tentu harus menggunakan pendekatan perundang-

\footnotetext{
5 Peter Mahmud Marzuki, , Penelitian Hukum, ed.rev.( Jakarta: Kencana Prenada Media Group, 2016), hlm. 35.

${ }^{6}$ Peter Mahmud Marzuki, Penelitian Hukum, ed.rev op cit, hlm. 29
} 
undangan, karena yang akan diteliti adalah berbagai aturan hukum yang menjadi fokus dari suatu penelitian. ${ }^{7}$ Pendekatan undangundang ini digunakan untuk menjawab permasalahan yang berkaitan dengan akibat hukum bagi Bank (Kreditur) bila Debitur wanprestasi dalam Perjanjian Kredit dengan Jaminan Hak Cipta, dan upaya yang dapat dilakukan Bank (Kreditur) dalam menyelesaikan Kredit Macet dengan Jaminan Hak Cipta.

Pendekatan Konseptual (conceptual approach), yakni beranjak dari pandanganpandangan dan doktrin doktrin yang berkembang di dalam ilmu hukum. dengan mempelajari pandangan pandangan dan doktrin doktrin dalam ilmu hukum, peneliti akan menemukan ide ide yang melahirkan pengertian pengertian hukum, konsep konsep hukum, dan asas asas hukum yang relevan dengan isu yang dihadapi. ${ }^{8}$ Pendekatan konseptual ini digunakan untuk menjawab permasalahan yang berkaitan Hak Cipta dapat dijadikan sebagai Jaminan Pokok dalam Perjanjian Kredit.

Bahan Hukum adalah bagian terpenting dalam penelitian hukum. Tanpa bahan hukm tidak akan mungkin dapat ditemukan jawaban atas isu hukum yang

${ }^{7}$ Ibid, hlm. 31.

${ }^{8}$ Ibid, hlm 95 diketengahkan. ${ }^{9}$ Penyusunan skripsi ini menggunakan bahan hukum primer, bahan hukum sekunder, dan bahan non hukum.

Analisa bahan hukum yang dipergunakan dalam penulisan skripsi ini adalah deskriptif normatif, yaitu suatu metode untuk memperoleh gambaran singkat mengenai permasalahn yang didasarkan pada analisa yang diuji dengan norma-norma dan kaidah-kaidah hukum yang berkaitan dengan masalah yang dibahas. Langkah-langkah yang digunakan dalam melakukan penelitian hukum: ${ }^{10}$

1. Mengidentifikasi fakta hukum dan mengeliminir hal hal yang tidak relevan untuk menetapkan isu hukum yang hendak dipecahkan;

2. Pengumpulan bahan-bahan hukum dan sekiranya dipandang mempunyai relevani juga bahan bahan non hukum;

3. Melakukan telaah atas isu hukum yang diajukan berdasarkan bahan bahan yang telah dikumpulkan;

4. Menarik kesimpulan dalam bentuk argumentasi yang menjawab isu hukum;

5. Memberikan preskripsi berdasarkan argumentasi yang telah dibangun di dalam kesimpulan.

\footnotetext{
9 Dyah Octhorina Susanti dan A'an Efendi, Penelitian Hukum (Legal Reseach) cet.2, op cit, hlm.48

${ }^{10}$ Ibid,hlm;173
} 


\section{PEMBAHASAN}

\subsection{Hak Cipta Sebagai Jaminan Pokok}

\section{Dalam Perjanjian Kredit}

Perjanjian Kredit merupakan salah satu bentuk Perjanjian, perjanjian berasal dari bahasa Belanda, yaitu overeenkomst. Untuk menerjemahkan istilah overeenkomst dikalangan ahli hukum masih banyak perbedaan pendapat. Ada yang menerjemahkan overeenkomst dengan perjanjian, tetapi ada pula yang menerjemahkan menjadi persetujuan. Perjanjian adalah suatu peristiwa dimana seorang berjanji kepada seorang lain atau dimana dua orang itu saling berjanji untuk melaksanakan suatu hal.

Kata "kredit" berasal dari Bahasa latin credere (Romawi) atau Vetrouwen (Belanda), dalam bahasa Inggris Trust of Confidence yang artinya adalah percaya. Kepercayaan menjadi unsur yang sangat penting dalam pergaulan hidup manusia pada umumnya, terlebih lagi pada hubungan hukum dalam bentuk perjanjian kredit. $^{11}$

Undang-Undang Perbankan Pasal 1 angka 11 memberikan pengertian:

Kredit adalah penyediaan uang atau tagihan yang dapat dipersamakan dengan itu, berdasarkan persetujuan

\footnotetext{
11 Mona, Bahan Ajar Perjanjian Kredit dan Jaminan,(Surabaya; Fakultas Hukum Muhammadiyah, 2003),hlm.8
}

atau kesepakatan pinjam meminjam antara bank dengan pihak lain yang mewajibkan pihak peminjam untuk melunasi utangnya setelah jangka waktu tertentu dengan pemberian bunga

Suatu kredit yang dikeluarkan oleh bank mempunyai risiko yang besar bagi bank itu sendiri, meskipun dari kredit tersebut bank mendapatkan keuntungan atas adanya bunga dalam pengembalian kredit tersebut. Risiko yang timbul inilah yang membuat bank membutuhkan suatu perlindungan yang menjamin keamanan dan kesehatan bank.

Bank untuk mencegah terjadinya risiko dalam menyalurkan kredit akan menerapkan prinsip kehati-hatian (Prudent Banking Principle), sebagaimana diatur dalam UU Perbankan pasal 2 dan pasal 29 ayat (2). Pasal 2 ; Perbankan Indonesia dalam melakukan usahanya berasaskan demokrasi ekonomi dengan menggunakan prinsip kehati-hatian.

Pasal 29 ayat (2) ; Bank wajib memelihara tingkat kesehatan bank sesuai dengan ketentuan kecukupan modal, kualitas aset, kualitas manajemen, likuiditas, rentabilitas, solvabilitas, dan aspek lain yang berhubungan dengan usaha bank, dan wajib melakukan kegiatan usaha sesuai dengan prinsip kehati-hatian.

Sebelum suatu fasilitas kredit diberikan, maka bank harus merasa yakin 
bahwa kredit yang diberikan benar-benar akan kembali. Keyakinan tersebut diperoleh dari hasil penilaian kredit sebelum kredit tersebut disalurkan. Kriteria penilaian kredit yang harus dilakukan oleh bank untuk mendapatkan nasabah yang benar-benar menguntungkan dilakukan dengan analisis $5 \mathrm{C}, 7 \mathrm{P}$, dan $3 \mathrm{R}$; Character; Capital; Capacity; Collateral; Condition of Economy. Prinsip 7P antaranya adalah Party, Personality; Purpose; Prospect; Payment, Profitability, Protection, sedangkan prinsip 3R antara lain Return; Repayment; Risk Bearing Ability. ${ }^{12}$

Salah satu unsur sistem analisis $5 \mathrm{C}$ adalah Collateral atau jaminan, walaupun tidak mengesampingkan unsur $\mathrm{C}$ lainnya, Collateral atau jaminan merupakan unsur yang penting didalam pelaksanaan pemberian kredit oleh Bank. Dalam hal jaminan KUHPerdata tidak menyebutkan adanya istilah jaminan umum dan jaminan khusus, akan tetapi dari peraturannya dapat diketahui mana jaminan yang bersifat umum dan mana jaminan yang bersifat khusus.

Jaminan yang bersifat umum yaitu jaminan yang diberikan oleh debitur kepada setiap kreditur, hak-hak tagihan mana tidak mempunyai hak saling mendahului atau dengan kata lain para

\footnotetext{
${ }^{12}$ Kasmir, Bank dan Lembaga Keuangan Lainnya, (Jakarta:.Raja Grafindo Persada, 2004), hlm: 35
}

kreditur mempunyai kedudukan yang sama (konkuren) ( pasal 1131 KUHPerdata). Jaminan yang bersifat khusus yaitu jaminan yang diberikan oleh debitur kepada kreditur hak-hak tagihan yang mempunyai hak mendahului dari kreditur lainnya sehingga kreditur ini mempunyai kedudukan yang lebih tinggi dari kreditur lainnya, kreditur ini disebut sebagai kreditur yang preferen (pasal 1132 KUHPerdata). ${ }^{13}$

Hak Cipta sebagai benda jaminan kredit dengan melalui lembaga jaminan Fidusia agar mempunyai kekuatan eksekutorial, maka jaminan hak cipta melalui Fidusia harus didaftarkan. UU Fidusia menetapkan pendaftaran fidusia, harus dilakukan dengan akta notaris. Ditetapkannya akta notaris dalam pembebanan jaminan fidusia dimaksudkan untuk mendapatkan nilai otentisitas dan memiliki kekuatan hukum yang mengikat sebagai alat bukti yang kuat bagi para pihak dan pihak ketiga termasuk ahli waris maupun orang yang meneruskan hak tersebut.Dengan dasar itu dibuat title eksekutorial pada sertifikat fidusia. ${ }^{14}$

Jaminan fidusia, objek jaminan tidak dikuasai oleh pemberi hutang (kreditur) melainkan tetap dikuasai oleh penghutang

13 Hasanudin Rahman, Aspek-aspek Pemberian Kredit Perbankan Indonesia, (Bandung: Citra Aditya Bakti, 2008,) hlm, 162

14 Tan Kamelo, Hukum Jaminan Fidusia Suatu Kebutuhan Yang didambakan, (Bandung; Alumni,.2004) ,hlm,213 
(debitur), dan tidak ada penyerahan fisik. Perjanjian fidusia wajib dilakukan secara tertulis yang dituangkan dengan akta notaris dan wajib pula dilakukan pendaftaran. Tanpa melakukan pendaftaran tidak akan lahir jaminan fidusia. Dengan demikian apabila suatu hak cipta akan dijadikan sebagai jaminan fidusia, maka suatu ciptaan itu harus didaftarkan terlebih dahulu di Direktorat Jenderal Kekayaan Intelektual. Pendaftaran ini penting sebagai bukti apabila terjadi wanprestasi, bahwa pemberi fidusia adalah pemegang hak cipta dan pelaksanaan eksekusi terhadap nilai ekonomi hak cipta dapat dilakukan melalui lembaga parate executie.

Peraturan Pemerintah Nomor 86 tahun 2000 tentang Tata Cara Pendaftaran Jaminan Fidusia dan Biaya Pembuatan Akta Jaminan Fidusia ditindak lanjuti dengan Keputusan Menteri Kehakiman dan Hak Asasi Manusia Republik Indonesia Nomor M-01.UM.01.06 Tahun 2000 tentang Bentuk Formulir Dan Tata Cara Pendaftaran Jaminan Fidusia, yang isinya;

1. Identitas pihak pemberi dan penerima yang meliputi: Nama lengkap; Tempat tinggal/tempat kedudukan; Pekerjaan.

2. Tanggal dan nomor akta Jaminan Fidusia, nama dan tempat kedudukan Notaris yang membuat akta jaminan fidusia
3. Perjanjian pokok yaitu mengenai macam perjanjian dan utang yang dijamin dengan fidusia.

4. Uraian mengenai benda yang menjadi obyek Jaminan Fidusia.

5. Nilai penjaminan

6. Nilai benda yang menjadi obyek Jaminan Fidusia.

Perjanjian kredit sebagai perjanjian pokok yang terjadi di Bank (kreditur) telah dilakukan kemudian Kreditur melakukan pembebanan benda Jaminan (Hak Cipta) sebagai perjanjian tambahan (accesoir) dan mendapatkan akta jaminan Fidusia, maka kedudukan Kreditur merupakan kreditur preferen, yang mempunyai hak didahulukan dari kreditur konkuren sebagaimana diatur dalam KUHPerdata pasal 1132 .

Surat Keputusan Dir. BI No. 26/68/Kep/Dir. Tanggal 7 September 1993 bank dalam pemberian kredit masih tetap mempertahankan faktor jaminan (collateral) sebagai salah satu prinsip dari “prudential banking”, setiap kredit yang diberikan bank harus terjamin pengembaliannya. Jaminan yang dapat dijadikan sebagai agunan adalah :

1. Jaminan Pokok yaitu : Hak Kebendaan yang timbul dari Benda Tidak bergerak dan Benda Bergerak baik berwujud maupun tidak berwujud (salah satunya Hak Cipta); 
2. Jaminan Tambahan yaitu jaminan perseorangan boleh diri pribadi atau perorangan.

Para pelaku industri kreatif ${ }^{15}$ yang tidak memilikvi aset fisik, berkaitan Hak Cipta dapat dijadikan jaminan merupakan suatu harapan untuk dapat mengembangkan usahanya, Hak Cipta sebagai suatu hak milik (property), dari segi sifat dan bentuknya, digolongkan sebagai benda bergerak tak berwujud (intangible goods). Hak cipta mempunyai prospek untuk dijadikan sebagai agunan kredit (collateral), karena hak cipta memiliki nilai ekonomi dan dapat dialihkan baik seluruhnya maupun sebagaian karena pewarisan, hibah, wasiat, perjanjian tertulis atau sebab-sebab lain yang dibenarkan oleh peraturan perundang-undangan.

Hak Cipta dapat dijadikan jaminan dalam perjanjian kredit, jaminan Hak Cipta masuk pada Jaminan Pokok yaitu Hak Kebendaan yang timbul dari Benda Bergerak tidak berwujud, pada realisasinya walaupun udah dua tahun sejak disahkannya UU Hak Cipta khususnya yang mengatur tentang hak cipta sebagai

\footnotetext{
${ }^{15}$ Kementerian Perdagangan Indonesia menyatakan bahwa Industri kreatif adalah industri yang berasal dari pemanfaatan kreativitas, keterampilan serta bakat individu untuk menciptakan kesejahteraan serta lapangan pekerjaan dengan menghasilkan dan mengeksploitasi daya kreasi dan daya cipta individu tersebut. (a.1; Periklanan, Arsitektur, Pasar Barang Seni, Kerajinan, Desain, Fesyen, Video, Film dan Fotografi, Musik, Seni Pertunjukan, Penerbitan dan Percetakan,dll).
}

objek jaminan fidusia, seniman dapat memperoleh pinjaman dari bank dengan menjaminkan karyanya. Hal ini tercantum dalam Pasal 16 ayat (3) yang menyatakan bahwa, "Hak Cipta dapat dijadikan sebagai objek jaminan fidusia", Kehadiran pasal ini tidak serta merta membuat bank dengan mudah memberikan pinjamannya. Pengaturan dalam Pasal 16 ayat (3) ini memang membutuhkan penjabaran lebih lanjut, sebagaimana pada ayat (4) bahwa "Ketentuan mengenai hak cipta sebagai objek jaminan fidusia sebagaimana dimaksud pada ayat (3) dilaksanakan sesuai dengan ketentuan peraturan perundangundangan." Hal ini terkait dengan jaminan bagi banknya sendiri untuk mendapatkan kepastian pengembalian dana yang telah dipinjamkan kepada seniman. Jaminan pengembalian dari pinjaman dengan jaminan hak cipta tidak lepas dari nilai sebuah lagu bisa laku atau tidak. Pada umumnya bank bersedia memberi utang kepada peminjam asalkan peminjam atau debitur menyediakan harta kekayaannya guna menjamin kelancaran utangnya. Karya cipta sebagai objek jaminan fidusia di Indonesia memang baru ada setelah lahirnya UU Hak Cipta. Hak cipta sudah memenuhi syarat yang ditentukan pada Pasal 1 butir 2 tersebut namun pihak perbankan di Indonesia belum mempraktikan hak cipta sebagai jaminan kredit karena terdapat beberapa hambatan dalam 
pelaksanaannya. Hambatan-hambatan tersebut berkaitan dengan masalah nilai, pasar, kepemilikan, dan kewenangan pengajuan hak cipta sebagai objek jaminan. Hambatan-hambatan tersebut timbul karena belum adanya regulasi yang khusus mengenai hak cipta sebagai objek jaminan. Keadaan tersebut menimbulkan risiko yang cukup besar bagi pihak perbankan untuk dapat menerima hak cipta sebagai suatu objek jaminan.

UU Hak Cipta sudah mengatur berkaitan dengan ketentuan hak cipta dapat dijadikan obyek jaminan fidusia. Hanya saja diperlukan peraturan yang lebih khusus seperti peraturan pelaksana dari undang-undang mengenai hak cipta dapat dijadikan jaminan kredit dengan melalui lembaga fidusia. Peraturan pelaksana ini diperlukan untuk memperjelas pelaksanaan dari hak cipta sebagai jaminan fidusia, terutama untuk penilaian secara ekonomi dari sebuah hak cipta, sehingga mempunyai kepastian hukum yang jelas.

\subsection{Akibat Hukum Bagi Bank (Kreditur) Bila Debitur Wanprestasi Dalam Perjanjian Kredit Dengan Jaminan Hak Cipta}

Perjanjian kredit pada dasarnnya adalah merupakan perjanjian utang piutang atau jenis perjanjian pinjam mengganti seperti halnya yang diterangkan
KUHPerdata dalam Pasal 1754, 1759, 1763 dan 1765 sebagai berikut:

Pasal 1754 KUHPerdata dijelaskan sebagai berikut :

"Pinjam pakai habis adalah suatu perjanjian yang menentukan pihak pertama menyerahkan sejumlah barang yang dapat habis terpakai kepada pihak kedua dengan syarat bahwa pihak kedua itu akan mengembalikan barang sejenis kepada pihak pertama dalam jumlah dan keadaan yang sama."

Pasal 1759 KUHPerdata dijelaskan sebagai berikut: "pemberi pinjaman tidak dapat meminta kembali barang yang dipinjamnkan sebelum lewat waktu yang telah ditentukan di dalam perjanjian."

Pasal 1763 KUHPerdata dijelaskan sebagai berikut: "barangsiapa meminjam suatu barang wajib mengembalikannya dalam jumlah dan keadaan yang sama dan pada waktu yang diperjanjikan."

Pasal 1765 KUHPerdata sebagai berikut: "untuk peminjaman uang atau barang yang habis dalam pemakaian, diperbolehkan membuat syarat bahwa atas pinjaman itu akan dibayar bunga."

Pengembalian kredit oleh Debitur, harapannya didalam pelaksanaannya berjalan lancar, namun kadang kala tidak sesuai dengan rencana atau timbul beberapa kendala didalam pembayaran angsuran. Kredit bermasalah pada mulanya 
selalu diawali dengan terjadinya "wanprestasi" (ingkar janji/cidera janji), yaitu suatu keadaan dimana debitur tidak mau dan atau tidak mampu memenuhi janji-janji yang telah dibuatnya sebagaimana tertera dalam Perjanjian Kredit. $^{16}$ Penyebab debitur wanprestasi dapat berupa overmacht atau kelalaian. Wanprestasi dapat juga disebabkan oleh pihak bank karena membuat syarat perjanjian kredit yang sangat memberatkan pihak debitur.

Wanprestasi menurut Subekti, dapat berupa empat kategori:

1. Tidak melakukan apa yang disanggupi akan dilakukan;

2. Melaksanakan apa yang dijanjikannya, tetapi tidak sebagaimana yang diperjanjikan;

3. Melakukan apa yang dijanjikan tetapi terlambat;

4. Melakukan sesuatu yang menurut perjanjian tidak boleh dilakukan. ${ }^{17}$

Bila terjadi Kredit bermasalah, Bank selaku kreditur, akan melakukan upaya penyelamatan kredit dengan cara Penjadwalan Kembali (Rescheduling), Persyaratan Kembali (Reconditioning), dan Penataan Kembali (Restructuring). Apabila

\footnotetext{
${ }^{16}$ Iswi Hariyani. Hapus Buku dan Hapus Tagih (Kredit macet Debitur UMKM di Bank BUMN), Surabaya: Bina Ilmu,2008), hlm:58.

17 Johanes Ibrahim. Cross Default and Cross Collateral Sebagai Upaya Penyelesaian Kredit Bermasalah, cetakan ke-1. (Bandung: Refika Aditama. 2004).hlm: 55-56.
}

langkah-langkah tersebut diatas telah dilakukan oleh Bank (kreditur) dan Debitur tidak mampu melakukan prestasinya yaitu terdapat tunggakan angsuran pokok dan/atau bunga yang telah melampaui 270 (dua ratus tujuh puluh) hari, maka hal ini dapat dikatakan kredit macet. Dengan demikian maka Debitur dapat dikatakan wanprestasi.

Wanprestasi berasal dari istilah aslinya dalam bahasa Belanda "wanprestatie" yang artinya tidak dipenuhinya prestasi atau kewajiban yang telah ditetapkan terhadap pihakpihak tertentu di dalam suatu perikatan, baik perikatan yang dilahirkan dari suatu perjanjian ataupun perikatan yang timbul karena undang- undang.

KUHPerdata Pasal 1238 :

"Si berhutang adalah lalai, apabila ia dengan surat perintah atau dengan sebuah akta sejenis itu telah dinyatakan lalai, atau demi perikatannya sendiri, ialah jika ia menetapkan, bahwa si berhutang harus dianggap lalai dengan lewatnya waktu yang ditentukan"

Jadi debitur dianggap melakukan wanprestasi dengan lewatnya batas waktu tersebut, apabila tidak ditentukan mengenai batas waktunya maka untuk menyatakan seseorang debitur melakukan wanprestasi, diperlukan surat peringatan tertulis dari kreditur yang diberikan kepada 
debitur. Faktor waktu dalam suatu perjanjian adalah sangat penting, karena dapat dikatakan bahwa pada umumnya dalam suatu perjanjian kedua belah pihak menginginkan agar ketentuan perjanjian itu dapat terlaksana secepat mungkin, karena penentuan waktu pelaksanaan perjanjian itu sangat penting untuk mengetahui tibanya waktu yang berkewajiban untuk menepati janjinya atau melaksanakan suatu perjanjian yang telah disepakati. Untuk menyatakan seseorang debitur melakukan wanprestasi, diperlukan surat peringatan tertulis dari kreditur yang diberikan kepada debitur. Surat peringatan tersebut disebut dengan somasi

Somasi adalah pemberitahuan atau pernyataan dari kreditur kepada debitur yang berisi ketentuan bahwa kreditur menghendaki pemenuhan prestasi seketika atau dalam jangka waktu seperti yang ditentukan dalam pemberitahuan itu dengan kata lain somasi adalah peringatan agar debitur melaksanakan kewajibannya sesuai dengan tegoran kelalaian yang telah disampaikan kreditur kepadanya.

Akibat hukum wanprestasi yang dilakukan oleh Debitur bagi Bank (Kreditur) berkaitan dengan Hak Cipta sebagai Jaminan kredit melalui lembaga Jaminan Fidusia sebagaimana KUHPerdata Pasal 1267 ada juga akibat hukum lainnya yaitu kedudukan Bank sebagai kreditur terhadap Debitur terhadap benda jaminan
Hak Cipta yaitu; Hak Cipta sebagai jaminan sudah didaftarkan di kantor pendaftaran fidusia dan Hak Cipta sebagai jaminan belum didaftarkan di kantor pendaftaran fidusia.

Pendaftaran jaminan fidusia dilaksanakan setelah melalui beberapa rangkaian perbuatan hukum sebelumnya, tahap pertama perbuatan hukum yang berupa pembuatan perjanjian pokok yang berupa perjanjian kredit atau perjanjian hutang baik dibuat dengan akta dibawah tangan atau akta otentik, akta otentik sebagai bukti yang sempurna artinya tidak memerlukan penambahan alat bukti lagi, bukti tersebut harus dianggap benar selama ketidakbenarannya tidak dibuktikan sebaliknya. Tahap kedua, tahap ini berupa pembebanan benda jaminan fidusia yang ditandatangani oleh penerima fidusia yaitu Bank selaku Kriditur dan pemberi fidusia atau Debitur atau pemilik benda jaminan.

Tahap ketiga, ditandai dengan pendaftaran Akta Jaminan Fidusia di Kantor Pendaftaran Fidusia. Bank melakukan pendaftaran bukan hanya melaksanakan kewajiban sesuai dengan UU Fidusia, akan tetapi untuk kepentingan dan keamanan Bank (Kreditur), karena didaftarkannya Jaminan Fidusia di Kantor Pendaftaran Fidusia maka kedudukan Bank selaku Kriditur mempunyai hak untuk didahulukan (Hak Preferen) sebagaimana diatur dalam KUHPerdata pasal 1132. 
Tujuan pendaftaran Fidusia ini selain untuk melahirkan hak kebendaan, juga untuk memperoleh kepastian hukum bagi para pihak dan pihak ketiga, hak-hak perorangan yang lahir dari perikatan ini berubah menjadi hak-hak kebendaan setelah dilakukan pendaftaran jaminan fidusia. Dalam hal pendaftaran jaminan fidusia, UU Fidusia tidak memberikan batas waktu kapan pendaftaran dilakukan. Dengaan didaftarkan benda jaminan dalam hal ni Hak Cipta, maka apabila debitur wanprestasi, akibat hukum adalah Bank (Kreditur) mempunyai kedudukan sebagai Kreditur yang mempunyai hak untuk didahulukan pelunasannya dari pada Kreditur Konkuren (biasa).

Perjanjian Kredit dengan Jaminan Fidusia, setelah pebuatan perjanjian pokok kemudian dilanjutan perjanjian tambahan yaitu untuk melakukan pem-bebanan benda jaminan, kadang kala Kreditur lalai atau tidak mendaftarkan benda jaminan baik benda tidak bergerak maupun benda bergerak termasuk Hak Cipta. Sebenarnya tidak ada ketentuan dalam UU Jaminan Fidusia yang mengatakan, bahwa fidusia yang tidak didaftarkan adalah tidak sah. Hanya saja untuk memberlakukakan ketentuan yang ada di dalam UU Jaminan Fidusia tersebut, maka haruslah dipenuhi syarat benda jaminan fidusia itu didaftarkan, sedangkan fidusia yang tidak didaftarkan, tidak dapat menikmati keuntungan-keuntungan dari ketentuan yang terdapat dalam UU Jaminan Fidusia Pasal 37 ayat (3) yang menyatakan bahwa: "Jika dalam jangka waktu sebagaimana dimaksud dalam ayat (2) tidak dilakukan penyesuaian, maka perjanjian Jaminan fidusia tersebut bukan merupakan hak agunan atas kebendaan sebagaimana dimaksud dalam Undang-Undang ini”.

Penjelasan dalam pasal ini di jelasakan "berdasarkan ketentuan ayat ini, maka perjanjian Jaminan Fidusia yang tidak didaftarkan tidak mempunyai hak yang didahulukan (preferen) baik di dalam maupun di luar kepailitan dan atau likuidasi". Jadi akibat hukum bagi Kreditur yang tidak melakukan pendaftaran benda jaminan Fidusia Hak Cipta maka sifatnya adalah Hak Pribadi artinya hak yang hanya dapat dipertahankan pada orang tertentu saja, sehingga tidak ada hak untuk didahulukan, kedudukannya sebagai kriditur konkuren atau biasa sebagai diatur dalam KUHPerdata pasal 1132 :

"Kebendaan tersebut menjadi jaminan bersama-sama bagi semua orang yang mengutangkan padanya; pendapatan penjualan benda-benda itu dibagi-bagi menurut kesimbangan, yaitu menurut besar kecilnya piutang masing-masing." 
3.3 Upaya Penyelesaian Yang Dapat Dilakukan Bank (Kreditur) Dalam Menyelesaikan Kredit Macet

\section{Dengan Jaminan Hak Cipta}

Penyelesaian kredit macet oleh Bank (Kreditur) apabila si Debitur wanprestasi pada umumnya dapat dilakukan melalui dua cara yaitu penyelesaian melalui Non Litigasi dan melalui Litigasi. Penyelesaian melaui non litigasi juga sering disebut sebagai upaya penyelamatan kredit. Upaya penyelamatan kredit adalah suatu langkah penyelesaian kredit bermasalah melalui perundingan kembali antar bank sebagai Kreditor dan nasabah sebagai Debitur. Upaya melalui Non Litigasi merupakan upaya yang dilakukan bank sebagai penawaran dari bank berdasarkan kesepakatan dengan Debitur untuk melakukan upaya penyelesaian tanpa melalui pengadilan umum. Sedangkan cara melalui Litigasi sering juga disebut dengan upaya penyelesaian kredit macet, penyelesaian kredit macet adalah upaya penyelesaian kredit macet yang dilakukan oleh bank melalui lembaga hukum. Upaya melalui Non litigasi antara lain adalah dengan cara Mediasi dan Negosiasi untuk mencapai kesepakatan antara para pihak.

Bank selaku kreditur, yang mempunyai kedudukan sebagai kreditur preferen karena mempunyai jaminan benda sebagaimana daitur dalam KUHPerdata pasal 1132 bahwa: “ .....kecuali apabila diantara para berpiutang itu ada alasanalasan yang sah untuk didahulukan”, Bank (kreditur) memegang jaminan fidusia atas benda bergerak tidak berwujud (Hak Cipta) yang telah dilakukan pendaftaran dan pembebannan serta mendapatkan sertifikat fidusia yang terdapat irah-irah "Demi Keadilan Berdasarkan Ketuhanan Yang Maha Esa", makna kalimat ini adalah sertifikat fidusia memiliki hak kekuatan eksekutorial yang dipersamakan dengan putusan Pengadilan berkekuatan tetap, artinya dengan sertifikat jaminan fidusia maka dapat langsung dieksekusi atau dilakukan penjualan benda jaminan tanpa melalui proses persidangan atau pemeriksaan melalui Pengadilan, dengan demikian apabila debitur wanprestasi, Bank (kreditur) dapat melakukan penjualan benda jaminan.

UU Fidusia pasal 29 ayat 1, Debitur dalam perjanjian kredit apabila wanprestasi, maka benda jaminannya akan dieksekusi, eksekusi benda jaminan dilakukan dengan cara :

1. Pelaksanaan Eksekutorial; didalam sertifikat fidusia terdapat irah-irah "Demi Keadilan Berdasarkan Ketuhanan Yang Maha Esa" mempunyai makna bahwa kekuatan sama dengan putusan pengadilan yang berkekuatan hukum tetap, sehingga ada dasar dalam melakukan penyitaan dan lelang atas benda jaminan fidusia; 
2. Pelelangan Umum; penjualan benda jaminan dilakukan dengan pelelangan umum yang melibatkan Kantor Lelang (KPKNL atau Balai Lelang Swasta), hasil penjualan lelang digunakan untuk melunasi pembayaran kepada Bank (Kreditur);

3. Penjualan dibawah Tangan; berbeda dengan pelelangan umum, penjualan dibawah tangan harus memenuhi beberapa persyaratan,

a. Adanya kesepakatan antara penerima benda jaminan ( Kreditur ) dengan pemberi fidusia (Debitur), bila dengan cara mendapatkan harga yang tinggi;

b. Adanya pemberitahuan kepada pihak-pihak yang berkepentingan oleh Penerima atau Pemberi fidusia;

c. Diumukan dimedia cetak ;

d. Pelaksanaan penjualan dilakukan setelah lewat 1 bulan sejak diberitahukan secara tertulis.

Eksekusi benda jaminan fidusia berupa Hak Cipta, berbeda dengan benda bergerak berwujud lainnya, karena benda jaminan Hak Cipta walaupun punya nilai ekonomi, namun sulit untuk mengukur berapa harga dari jaminan Hak cipta karena dibutuhkan suatu lembaga atau perorangan yang dapat menilai besaran nilai ekonominya itu, sedangkan benda bergerak lainnya mudah dinilai harganya (misalnya sepeda motor, atau barang elektronik).

Selain dengan eksekusi benda jaminan, cara lain dalam menyelesaikan kredit macet bila debitur wanprestasi yaitu dengan jalan melalui Litigasi yaitu penyelesaian sengketa perjanjian kredit dengan Hak Cipta sebagai jaminannya yang terjadi akibat Debitur wanprestasi dapat diselesaikan melalui jalur litigasi. Dalam hal ini Kreditur mengajukan gugatan ke pengadilan negeri. Penyelesaian sengketa yang dilakukan melalui jalur litigasi harus dijadikan pilihan terakhir jika sudah tidak berhasil menemukan cara-cara penyelesaian alternatif di luar proses pengadilan, jangan sampai cara litigasi yang dipilih malah menjadi tidak efektif karena hasil putusannya sulit dieksekusi, serta tidak efisien karena prosesnya berjalan lama dikarenakan salah satu pihak yang diputus oleh pengadilan bersalah maka pihak yang dinyatakan kalah dalam sengketa perdata tersebut bisa melakukan banding, kasasi atau sampai pada peninjauan kembali, mahal, dan berbelit-belit. 


\section{PENUTUP}

\subsection{Kesimpulan}

1. Hak cipta belum dapat dijadikan sebagai jaminan pokok perjanjian kredit dikarenakan Hak Cipta merupakan jaminan baru terdapat kesulitan untuk menilai ekonominya dan belum ada peraturan yang mengatur lebih lanjut, Lembaga Perbankan pada prakteknya belum bisa menerima jaminan Hak Cipta sebagai jaminan pokok hanya sebagai jaminan tambahan saja. Pada UU Hak Cipta pasal 16 ayat (3) mengatur jaminan hak cipta.

2. Akibat hukum bagi Kreditur bila Debitur wanprestasi, hal ini berkaitan dengan benda jaminan Hak Cipta, bila Hak Cipta sebagai jaminan fidusia didaftarkan di Kantor Pendaftaran Fidusia berakibat Kreditur mempunyai hak untuk didahulukan (Kreditur Preferen), bila hak cipta sebagai jaminan fidusia tidak didaftarkan di Kantor Pendaftaran Fidusia dianggap batal demi hukum jaminan fidusianya sehingga kedudukannya sebagai kreditur kongkuren yang hanya mempunyai hak Pribadi (Persoonlijke).

3. Upaya penyelesaian yang dapat dilakukan Bank sebagai Kreditur apabila Debitur wanprestasi dengan jaminan hak cipta dengan cara melakukan upaya penyelamatan yaitu dengan cara Penjadwalan Kembali (Rescheduling), Persyaratan Kembali (Reconditioning), dan Penataan Kembali (Restructuring). Apabila upaya penyelamatan tidak berhasil maka dilakukan eksekusi grosse akta (Pelaksanaan Eksekutorial, Pelelangan Umum, dan Penjualan dibawah Tangan) dan penyelesaian lainnya yaitu melalui Litigasi, dengan mengajukan gugatan ke Pengadilan Negeri.

\subsection{Saran}

1. Kepada Pemerintah segera menerbitkan peraturan-peraturan yang berkaitan dengan penggunaan Hak Cipta sebagai agunan kredit di Lembaga Perbankan, sehingga bank selaku kreditur mendapatkan kepastian pengembalian dana yang telah dipinjamkan kepada Debitur;

2. Kepada Otoritas Jasa Keuangan (OJK) segera melakukan perbaikan-perbaikan berkaitan dengan pengaturan tentang benda-benda Jaminan atau Agunan Kredit dalam perjanjian Kredit

3. Kepada Pemerintah segera membentuk lembaga penilai yang memiliki kemampuan untuk memberikan penilaian terhadap nilai ekonomi dari hak cipta 


\section{DAFTAR PUSTAKA}

\section{Buku}
A.A. Andi Prajidno , 2011, Hukum Fidusia, Bayu Media Publik, Malang.

Abdulkadir Muhammad, 2000, Hukum Perdata Indonesia, Citra Aditya Bakti,Bandung.

2002, Hukum Perikatan, Citra Aditya Bakti, Bandung. 2004, Segi Hukum Lembaga Keuangan dan Pembiayaan, Citra Aditya Bakti, Bandung.

Abdulkadir Muhammad, Rilda Murniati, 2004, Lembaga Keuangan dan Pembiayaan, Citra Aditya Bakti, Bandung.

Dadang Husen Sobana, 2016, Hukum Perbankan Di Indonesia, Pustaka Setia, Bandung.

Dyah Octhorina Susanti, 2011, Makalah Teori Perlindungan Hukum, Pasca Sarjana Ilmu Hukum Universitas Islam Kadiri (UNISKA ), Kediri.
Dyah Octhorina Susanti dan A'an Efendi, 2015, Penelitian Hukum (Legal Reseach) cet.2, Sinar Grafika, Jakarta.

Gatot Supramono, 1996, Perbankan dan Permasalahan Kredit : Suatu Tinjauan Yuridis,: Djambatan, Jakarta.

Handri Raharjo, Hukum Perjanjian di Indonesia, Pustaka Yustisia, Yogyakarta.

Hermansyah, 2011, Hukum Perbankan Nasional Indonesia, edisi revisi, cet. ke-6 Kencana, Jakarta.

Iswi Hariyani, 2010, Prosedur Mengurus HAKI (Hak Atas Kekayaan Intelektual) yang Benar, Penerbit Pustaka Yustisia,Yogyakarta.

Johannes Ibrahim, 2004, Kartu Kredit Dilematis Antara Kontrak dan Kejahatan, Refika Aditama, Bandung.

Kasmir, 2004, Bank dan Lembaga Keuangan Lainnya, Raja Grafindo Persada, Jakarta. 
Leden Marpaung, 2009, Tindak Pidana

Dibidang Hak Cipta, Sinar Grafika, Jakarta.

Mariam Darus Badrulzaman, 2000, Perjanjian Kredit Bank, Citra Aditya Bakti,Bandung.

Moch.Isnaeni, 1986, Hipotek Pesawat Udara di Indonesia, Dharma Muda, Surabaya.

Muhammad Djumhana, 2011, Hukum Perbankan Di Indonesia, Citra Aditya Bakti, Bandung.

Muhammad Djumhana dan R. Djubaedillah, 2003. Hak Milik Intelektual (Sejarah, Teori dan Prakteknya Di Indonesia), Citra Aditya Bakti, Bandung.

Munir Fuadi, 2003, Hukum Perbankan Modern, Citra Aditya Bakti, Bandung.

Nindyo Pramono, 2006, Hukum Bisnis Aktual, Citra Aditya Bakti, Bandung.

Peter Mahmud Marzuki,2016, Penelitian Hukum, Kencana Prenada Media Group, Jakarta.
Philipus M Hadjon, 2007, Pengantar Hukum Administrasi Indonesia. Gadja Mada University Press, Yogyakarta.

Rahmadi Usman, 2003, Aspek-Aspek Hukum Perbankan Di Indonesia, Gramedia Pustaka Utama, Jakarta.

Sentosa Sembiring, 2000, Hukum Perbankan, Mandar Maju, Bandung.

Setiawan, 1994, Pokok-Pokok Hukum Perikatan, Bina Cipta, Bandung.

Sri Soemantri, 1992, Bunga Rampai Hukum Tata Negara Indonesia, Alumni, Bandung.

Subekti, 2008, Hukum Perjanjian, Intermasa, Jakarta. 1996, Jaminan-Jaminan untuk Pemberian Kredit Menurut Hukum Indonesia, Citra Aditya Bakti, Bandung.

Sutarno, 2009, Aspek-aspek Hukum Perkreditan Pada Bank, Alfabeta, Bandung.

Thomas Suyatno,dkk, 2007, Dasar-Dasar Perkreditan, Gramedia Pustaka Utama, Jakarta 
Zainal Asikin, 2015, Pengantar Hukum

Perbankan Indonesia, Raja Grafindo Persada, Jakarta.

\section{Peraturan Perundang-Undangan}

Kitab Undang-Undang Hukum Perdata (KUHPerdata);

Undang- Undang Nomor 10 Tahun 1998 tentang Perubahan Atas UndangUndang Nomor 7 Tahun 1992 tentang Perbankan;

Undang-Undang Nomor 42 Tahun 1999 tentang Fidusia;

Undang-Undang Nomor 28 Tahun 2014 tentang Hak Cipta;

Peraturan Bank Indonesia Nomor 14/15/2012 tentang Penilaian Kualitas Asset Bank Umum

\section{Sumber Internet}

www.hukumonline.com./ Tanya Jawab Hukum Perdata.

http://statushukum.com/perlindunganhukum.

http://www.scribd.com/doc/27157439/Ban k-dan-Lembaga-Keuangan-lainnya. http://www.seputarpengetahuan.com, pengertian -lembaga-keuanganmenurut-para-ahli . 


\section{BIODATA SINGKAT PENULIS}

Riandhyka Rahandono (031814253013), Azizul Hakiki (031814153012), dan Achmad Rifqi Nizam (031814153003) sedang menempuh pendidikan Magister pada Program Pasca Sarjana Fakultas Hukum, Universitas Airlangga Surabaya. 